\title{
Differential susceptibility and resistance to glyphosate in annual ryegrass and wavy-leaved fleabane
}

\author{
Flávia Regina da Costa, Humberto Henrique Ansolin and Leonardo Bianco de Carvalho \\ Department of Agronomy, Santa Catarina State University, 88520-000 Lages SC, Brazil
}

\begin{abstract}
Annual ryegrass (Lolium multiflorum) and wavy-leaved fleabane (Conyza bonariensis) were tested, aiming to investigate the dose-response of biotypes of both species to glyphosate. Glyphosate herbicide at doses varying from 0 up to $1.440 \mathrm{~g}$ e.a. ha $^{-1}$ was sprayed onto annual ryegrass plants showed four leaves and wavy-leaved fleabane showed three pair of leaves. The fresh weight of shoot was obtained at 21 days after herbicide application. The response of biotypes of $L$. multiflorum and $C$. bonariensis to glyphosate was clearly different. For $L$. multiflorum, the S2, R1, and R3 biotypes supported glyphosate doses 1.5, 3.0, and 8.3 times higher than the biotype S1. For $C$. bonariensis, the $\mathrm{S} 2$ and $\mathrm{R}$ biotypes supported glyphosate doses 2.0 and 15.5 times higher than the biotype $\mathrm{S} 1$. We found a low glyphosate-resistant (R1) and a high glyphosate-resistant (R2) biotypes of $L$. multiflorum, in agricultural regions where other biotypes had been found. In addition, a high glyphosate-resistant $(\mathrm{R})$ biotype of $C$. bonariensis was identified in an agricultural area of Santa Catarina State, Brazil, where weed resistant was not previously found.
\end{abstract}

Keywords: Conyza bonariensis, Lolium multiflorum, $\mathrm{N}$-(phosphonomethyl)glycine, dose-response, weed resistance. 


\section{INTRODUCTION}

Annual ryegrass (Lolium multiflorum) and wavy-leaved fleabane (Conyza bonariensis) are two important weeds of annual and perennial crops in Brazil and worldwide. Both species were also found as resistant to glyphosate (Heap 2014). Herbicide resistance has been one of the most important challenges in agricultural systems in recent years, with cases of herbicide resistance having increased exponentially in the last three decades (Heap 2014). Strong selection by herbicides has resulted in the widespread evolution of herbicide resistance in populations of agricultural weeds (Jasieniuk et al. 2008). Weed populations evolve resistance in response to repeated treatment with herbicides having the same mechanism of action or metabolic degradation pathway (reviewed in Gressel 2002, Duke and Powles 2008, Powles 2008, Powles and $Y u$ 2010). There were found 434 unique cases (species $\mathrm{x}$ site of action) of herbicide resistant weeds globally, with 237 species (138 dicots and 99 monocots) (Heap 2014). Also according to that author, weeds have evolved resistance to 22 of the 25 known herbicide sites of action and to 155 different herbicides, being reported in 82 crops in 65 countries.

The resistance to glyphosate is an important example of herbicide resistance. This herbicide has been used extensively in agriculture worldwide for over $30 \mathrm{yr}$, and, today, it is the most commercialized herbicide in the world (Duke and Powles 2008). Glyphosate has a unique chemical structure and a molecular target site related to the inhibition of the 5enolpyruvylshikimate-3-phosphate synthase (EPSPS) (EC 2.5.1.19) in the shimikate pathway (Duke et al. 2003). Inhibition of this enzyme results in starvation of EPSP and ensuing metabolic products, such as the aromatic acids phenylalanine, tyrosine, and tryptophan that are required for protein synthesis (Herrman and Weaver 1999, Siehl 1997). However, a more rapid and dramatic effect is the accumulation of precursors of the chorismate pathway, most notably shikimate (Amrhein et al. 1980, Lydon and Duke 1988).

The resistant to herbicides can occur at different levels, as well as the susceptibility of plants in the populations. So, the objective of this research was to investigate the dose-response of biotypes of L. multiflorum and $C$. bonarinesis to glyphosate.

\section{MATERIAL AND METHODS}

Seeds of annual ryegrass and wavy-leaved fleabane were collected from urban areas with no glyphosate application in Lages, SC, Brazil, in 2012. In addition, seeds from the species were also collected from agricultural areas in South of Brazil (Santa Catarina State and Rio Grande do Sul State), in 2012.

Seeds of both species were sowed in $300 \mathrm{~mL}$ plastic pots filled with commercial substrate. Plants grew under controlled conditions, in a growth chamber with temperature of $25{ }^{\circ} \mathrm{C}$, humidity of $60 \%$, and photoperiod of $14 \mathrm{~h}$ delivered by incandescent lights $\left(800 \mu \mathrm{mol} \mathrm{m} \mathrm{m}^{-2} \mathrm{~s}^{-1}\right)$.

Glyphosate herbicide was sprayed at doses of 0 , $5.625,11.25,22.5,45,90,180,360,720$, and $1.440 \mathrm{~g}$ e.a. ha ${ }^{-1}$, by using a $\mathrm{CO}_{2}$-backpack equipped with four flat fan nozzles (TeeJet $80.02 \mathrm{VS}$ ), delivering $200 \mathrm{~L} \mathrm{ha}^{-1}$. The herbicide application occurred when annual ryegrass plants showed four leaves and wavyleaved fleabane showed three pair of leaves.

The glyphosate doses represented the experimental treatments (10 doses), replicated six times.

The fresh weight of plant shoot was weighted (semi-analytical balance $-0.00001 \mathrm{~g}$ ) at 21 days after the herbicide application. Data were submitted to regression analysis, according to the non-linear, log-logistic equation:

$$
y=\min +(\max -\min ) /\left[1+\left(x^{\wedge} \text { Hillslope/EC50) }\right]\right.
$$

where: $\min$ and $\max$ are the minimum and the maximum value of fresh weight, EC50 is the inflexion point of the curve, representing the dose required to reduce plant fresh weight by $50 \%$, and Hillslope is the slope of the curve at EC50.

Statistical analysis was performed by using SigmaPlot $^{\circledR}$ (Systat, versão 10.0, EUA), that uses Kolmogorov-Smirnov test to check the residual normality and the Spearman Rank correlation test between absolute values of residues and absolute values of dependent variables to check the constancy of variances.

\section{RESULTS}

The response of biotypes of $L$. multiflorum and C. bonariensis to glyphosate was clearly different (Figure 1). In general, $C$. bonariensis biotypes supported higher glyphosate doses than the biotypes of $L$. multiflorum. In addition, some biotypes supported the glyphosate exposure at low doses with no fresh weight reduction, mainly the $\mathrm{R}$ biotypes. On the other hand, glyphosate doses higher than $100 \mathrm{~g}$ a.e. ha ${ }^{-1}$ caused more fresh weight reduction of the $S$ biotypes than the R biotypes, for both species. Moreover, the highest dose of glyphosate used in this experiment reduced the fresh weight by $89 \%, 88 \%, 86 \%, 79 \%$ for the biotypes of $L$. multiflorum (S1, S2, R1, and R2, respectively), and by $90 \%, 70 \%$, and $30 \%$ for the biotypes of $C$. bonariensis (S1, S2 and $\mathrm{R}$, respectively). 
Lolium multiflorum



Conyza bonariensis

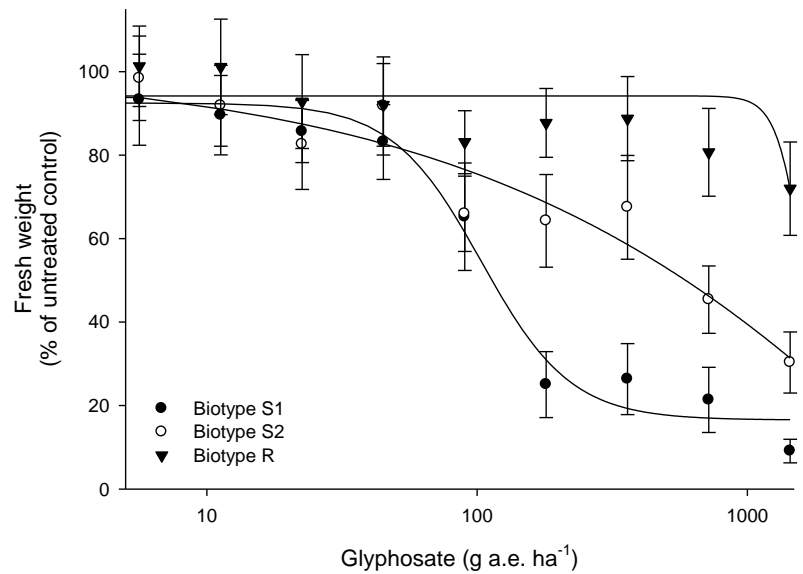

Figure 1. Curves of dose-response to glyphosate of biotypes of annual ryegrass (Lolium multiflorum) and wavy-leaved fleabane (Conyza bonariensis). Vertical lines indicate the standard error of mean. S and R indicate the biotype showed susceptibility or resistance to glyphosate, respectively.

Table 1. Equation parameters, partial ANOVA, complementary analysis (CVT and NT), and factor of resistance (FR) of biotypes of annual ryegrass (Lolium multiflorum).

\begin{tabular}{|c|c|c|c|c|c|c|c|c|c|c|}
\hline \multirow{2}{*}{ Biotype } & \multicolumn{4}{|c|}{ Equation parameters } & \multicolumn{3}{|c|}{ ANOVA $^{1 / 2}$} & \multirow{2}{*}{$\mathrm{CVT}^{/ 3}$} & \multirow{2}{*}{$\mathrm{NT}^{1 / 4}$} & \multirow{2}{*}{$\mathrm{FR}^{15}$} \\
\hline & $\min$ & $\max$ & EC50 & Hillslope & $\mathrm{R}^{2}$ & $\mathrm{~F}$ & $P$ & & & \\
\hline S1 & 10.7 & 113.3 & 35 & 1.605 & 0.94 & 45.57 & $<0.001$ & 0.101 & 0.581 & 1.0 \\
\hline S2 & 6.1 & 99.1 & 52 & 0.960 & 0.89 & 26.02 & $<0.001$ & 0.682 & 0.542 & 1.5 \\
\hline $\mathrm{R} 1$ & 12.1 & 106.1 & 104 & 2.574 & 0.99 & 532.75 & $<0.001$ & 0.086 & 0.752 & 3.0 \\
\hline R2 & 21.1 & 114.6 & 290 & 2.871 & 0.94 & 44.09 & $<0.001$ & 0.076 & 0.999 & 8.3 \\
\hline
\end{tabular}

${ }^{\pi}$ Regression equation: $y=\min +(\max -\min ) /\left[1+\left(x^{\wedge}\right.\right.$ Hillslope/EC50)], where min and max are the minimum and the maximum value of fresh weight, EC50 is the inflexion point of the curve, representing the dose required to reduce plant fresh weight by $50 \%$, and Hillslope is the slope of the curve at EC50. ${ }^{12}$ ANOVA: $R^{2}, F$, and $P$ represent the value of the coefficient of determination of the curve, the value of $F(F$ test) and the value of $\mathrm{P}$ (significance of $\mathrm{F}$ test), respectively. ${ }^{13} \mathrm{CVT}$ is the value of significance for constant variance test. ${ }^{14} \mathrm{NT}$ is the value of significance for residual normality test. ${ }^{15} \mathrm{FR}=\mathrm{EC} 50(\mathrm{~S} 2, \mathrm{R} 1$, or R2) / EC50(S1).

Table 1. Equation parameters, partial ANOVA, complementary analysis (CVT and NT), and factor of resistance (FR) of biotypes of wavy-leaved fleabane (Conyza bonariensis).

\begin{tabular}{|c|c|c|c|c|c|c|c|c|c|c|}
\hline \multirow{2}{*}{ Biotype } & \multicolumn{4}{|c|}{ Equation parameters } & \multicolumn{3}{|c|}{ ANOVA $^{12}$} & \multirow{2}{*}{$\mathrm{CVT}^{/ 3}$} & \multirow{2}{*}{$\mathrm{NT}^{/ 4}$} & \multirow{2}{*}{$\mathrm{FR}^{15}$} \\
\hline & $\min$ & $\max$ & EC50 & Hillslope & $\mathrm{R}^{2}$ & $\mathrm{~F}$ & $P$ & & & \\
\hline S1 & 14.6 & 93.1 & 105 & 2.32 & 0.96 & 70.14 & $<0.001$ & 0.14 & 0.94 & 1.0 \\
\hline S2 & 15.7 & 99.7 & 211 & 0.87 & 0.95 & 58.16 & $<0.001$ & 0.95 & 0.97 & 2.0 \\
\hline$R^{16}$ & 8.3 & 94.2 & 1,623 & 8.72 & 0.78 & 10.87 & $<0.05$ & 0.23 & 0.96 & 15.5 \\
\hline
\end{tabular}

${ }^{\pi}$ Regression equation: $y=\min +(\max -\min ) /\left[1+\left(x^{\wedge}\right.\right.$ Hillslope/EC50)], where min and max are the minimum and the maximum value of fresh weight, EC50 is the inflexion point of the curve, representing the dose required to reduce plant fresh weight by $50 \%$, and Hillslope is the slope of the curve at EC50. ${ }^{12}$ ANOVA: $R^{2}, F$, and $P$ represent the value of the coefficient of determination of the curve, the value of $F(F$ test) and the value of $\mathrm{P}$ (significance of $\mathrm{F}$ test), respectively. ${ }^{13} \mathrm{CVT}$ is the value of significance for constant variance test. ${ }^{14} \mathrm{NT}$ is the value of significance for residual normality test. ${ }^{15} \mathrm{FR}=\mathrm{EC} 50\left(\mathrm{~S} 2\right.$ or $\mathrm{R}$ ) / EC50(S1). ${ }^{16}$ Although the regression analysis was consistent, the EC50 of the R biotype was found at doses higher than the ones tested in the experiment.

The dose required to reduce the fresh weight of L. multiflorum by $50 \%$ was $35,52,104$, and $290 \mathrm{~g}$ a.e. ha ${ }^{-1}$, respectively for the $\mathrm{S} 1, \mathrm{~S} 2, \mathrm{R} 1$, and $\mathrm{R} 2$ biotypes (Table 1). Thus, the factor of resistance found was $1.0,1.5,3.0$, and 8.3 for the $\mathrm{S} 1, \mathrm{~S} 2, \mathrm{R} 1$, and R2 biotypes, indicating that $\mathrm{S} 2, \mathrm{R} 1$, and $\mathrm{R} 3$ supported glyphosate doses $1.5,3.0$, and 8.3 times higher than the biotype $\mathrm{S} 1$.

The dose required to reduce the fresh weight of C. bonariensis by $50 \%$ was 105,211 , and
$1,623 \mathrm{~g}$ a.e. $\mathrm{ha}^{-1}$, respectively for the $\mathrm{S} 1$, S2, and $\mathrm{R}$ biotypes (Table 2). Thus, the factor of resistance found was $1.0,2.0$, and 15.5 for the S1, S2, and R biotypes, indicating that $\mathrm{S} 2$ and $\mathrm{R}$ supported glyphosate doses 2.0 and 15.5 times higher than the biotype S1.

We assumed that the adjusted regression curves were adequate, since all regressions were significant $(P<0.05)$, all variances were constant $(P>0.05)$, and all residues were normally distributed $(P>0.05)$. 


\section{DISCUSSION}

For L. multiflorum, the S1 and S2 biotypes were found as susceptible to glyphosate, since the FR was lower than 2.0 (Table 1). On the other hand, the R1 biotype showed lower susceptibility to glyphosate than $\mathrm{S} 1$ and S2, and the FR of 3.0 indicates that biotype can show resistance to glyphosate at low level. The FR higher than 8.0 of the R2 biotype indicates that biotype showed resistant to glyphosate, supporting doses higher than eight times greater than a highly susceptible biotype.

For $C$. bonariensis, the $\mathrm{S} 1$ and $\mathrm{S} 2$ biotypes were found as susceptible to glyphosate, since the FR was up to 2.0 (Table 2). On the other hand, the $\mathrm{R}$ biotype showed lower susceptibility to glyphosate than S1 and S2, and the FR of 15.5 indicates that biotype show resistance to glyphosate, supporting doses higher than fifteen times greater than a highly susceptible biotype.

In Brazil, first cases of resistance to glyphosate reported for biotypes of $L$. multiflorum (Roman et al. 2004, Vargas et al. 2004) and C. bonariensis (Vargas et al. 2007, Lamego and Vidal 2008), in both annual and perennial crops. To date, new resistant biotypes have been found (Heap 2014), indicating that the problem of weed resistance, especially with glyphosate, is increasing, so that efforts must be done to prevent the evolution of new weed resistant populations.

In our study, new populations suspected to be resistant to glyphosate were tested. We found a biotype of $C$. bonariensis from Campos Novos, SC, Brazil, showing resistance to glyphosate at high level ( $F R=15.5)$. In addition, we also found two biotypes of L. multiflorum resistant to glyphosate in agricultural areas where other resistant biotypes had been found. The presence of new biotypes in agricultural areas indicates that the resistant populations are spreading faster than we are solving the issue, and then the problem of weed resistance is increasing.

It is essential to know whether or not a lack of weed control after glyphosate application results from herbicide resistance or other reasons (Duke and Powles 2008; Powles 2008). For example, when using herbicides at a sublethal dose, some plants are affected but survive, and therefore, there can be a rapid resistance evolution (Neve and Powles 2005a,b). In the case of $L$. multiflorum, plants cannot be killed using glyphosate when the herbicide is applied after the plant affiliates or attains the flowering stage. In the case of $C$. bonariensis, the aboveground parts of well-developed plants can be killed, but the plant can re-grow by basal meristems. On the other hand, seedlings can be controlled successfully. The use of glyphosate on advanced growth-stage plants may have exacerbated the development of glyphosate resistance in sourgrass.

Using the identification of herbicide-resistant weeds as a first step in resistance management demands an efficient and effective screening test; only after obtaining an accurate diagnosis can the nature, distribution and abundance of resistant weed populations be monitored (Perez and Kogan 2003). In addition, understanding the factors influencing the evolution of glyphosate resistance will help delay the appearance of resistance (Preston et al. 2009). For $C$. bonariensis and $L$. multiflorum, the main factors can be cited as intensive use of glyphosate and the lack of other weed management practices. Orchards and fallow situations are at high risk of glyphosate resistance evolution. In addition for $L$. multiflorum, the fact of being a plant used as pasture, the commerce of not-certified seeds can increase the problem of spreading resistant biotypes. Thus, changing management practices to include other weed control tactics will help delay the evolution of glyphosate resistance in this species, whereas the use of glyphosate as the only control method will exacerbate glyphosate resistance.

\section{CONCLUSION}

Dose-response experiments allow us to conclude that we found a low glyphosate-resistant and a high glyphosate-resistant biotypes of L. multiflorum, in agricultural regions where other biotypes had been found. In addition, a high glyphosate-resistant biotype of $C$. bonariensis was identified in an agricultural area of Santa Catarina State, Brazil, where weed resistant was not previously found.

\section{Acknowledgements}

The authors thank to CAPES from Government of Brazil for the Post-graduate scholarship of the first author.

\section{References}

Amrhein N, Deus B, Gehrke P, Steinrücken HC. 1980. The site of the inhibition of the shikimate pathway by glyphosate: II. Interference of glyphosate with chorismate formation in vivo and in vitro. Plant Physiol 66: 830-834.

Duke SO, Baerson SR, Rimando AM. 2003. Herbicides: glyphosate. pp. 708-869. In: Plimmer JR, Gammon DW, Ragsdale NN (Eds.). Encyclopedia of Agrochemicals. New York: John Wiley.

Duke SO, Powles SB. 2008. Glyphosate: a once in a century herbicide. Pest Manag Sci 64: 319-325.

Gressel J. 2002. Evolution of resistance to herbicides. pp. 78-121. In: Gressel J (Ed). Molecular Biology of Weed Control. New York: Taylor \& Francis.

Heap IM. 2014. International Survey of Herbicide-Resistant weeds. http://www.weedscience.org. Accessed: June 6, 2014.

Herrman KM, Weaver LM. 1999. The shikimate pathway. Annu Rev Plant Physiol Plant Mol Biol 50: 473-503. 
Jasieniuk M, Ahmad R, Sherwood AM, Firestone JL, Perez-Jones A, Lanini WT, Mallory-Smith C, Stednick Z. 2008. Glyphosateresistant Italian ryegrass (Lolium multiflorum) in California: distribution, response to glyphosate, and molecular evidence for an altered target enzyme. Weed Sci 56: 496-502.

Lamego FP, Vidal RA. 2008. Resistance to glyphosate in Conyza bonariensis and Conyza canadensis biotypes in Rio Grande do Sul, Brazil. Planta Daninha 26: 467-471.

Lydon J, Duke SO. 1988. Glyphosate induction of elevated levels of hydroxybenzoic acids in higher plants. J Agric Food Chem 36: 813-818.

Neve P, Powles SB. 2005a. Recurrent selection with reduced herbicide rates results in the rapid evolution of herbicide resistance in Lolium rigidum. Theor Appl Genet 110: 1154-1166.

Neve P, Powles SB. 2005b. High survival frequencies at low herbicide use rates in populations of Lolium rigidum result in rapid evolution of herbicide resistance. Heredity 95: 485-492.

Perez A, Kogan M. 2003. Glyphosate-resistant Lolium multiflorum in Chilean orchards. Weed Res 43: 12-19.

Powles SB. 2008. Review. Evolved glyphosate-resistant weeds around the world: lessons to be learnt. Pest Manag Sci 64: 360365.

Powles SB, Yu Q. 2010. Evolution in action: plants resistant to herbicides. Annu Rev Plant Biol 61: 317-347.

Preston C, Wakelin AM, Dolman FC, Bostamam Y, Boutsalis P. 2009. A decade of glyphosate-resistant Lolium around the world: mechanisms, genes, fitness, and agronomic management. Weed Sci 57: 435-441.

Roman ES, Vargas L, Rizzardi MA, Mattei RW. 2004. Resistance of Italian ryegrass (Lolium multiflorum) to glyphosate. Planta Daninha 22: 301-306.

Siehl DL. 1997. Inhibitors of EPSPS synthase, glutamine synthetase and histidine synthesis. pp. 37-67. In: Roe RN, Burton JD, Kuhr RJ (Eds). Herbicide activity: toxicology, biochemistry and molecular biology. Amsterdam: IOS Press.

Vargas L, Bianchi MA, Rizzardi MA, Agostinetto D, Dal Magro T. 2007. Conyza bonariensis biotypes resistant to the glyphosate in Southern Brazil. Planta Daninha 25: 573-578.

Vargas L, Roman ES, Rizzardi MA, Silva VC. 2004. Identification of glyphosate-resistant ryegrass (Lolium multiflorum) biotypes in apple orchards. Planta Daninha 22: 617-622. 